THE CADDIS-FLIES (TRICHOPTERA) OF JAPAN. I.FAMILY PHRYGANEIDA.

BY WARO NAKAHARA, HONGOKU, TOKIO, JAFAN.

Through the kindress of Mr. Miyake, who has generously permitted the frce use of the valuable literature and collections in his possession, and has given me much valuable advice, I have recently had the opportunity of studying Japanese caddis-flies or Trichoptera. The purpose of the present study is to record the species known from Japan, offering such notes as may suggest themselves, and to describe any forms that appear to be unknown.

The present paper deals with the family Phryganeidæ, which includes some of the most beautiful caddis-flies in the world.

FAM. PHRYGANEIDA.

Genus Neuronia Leach.

1. Neuronia regina Maclachlan.

Holostomis regina MacLachlan-Journ, Linn. Soc. London, Zool., XI, p. 104 (1871); Matsumura, Thous. Ins. Jap., i, p. 165, P1. XII, fig. 11, o (1904).

Neuronia regina Ulmer-Cat. Coll. Selys, Fasc. VI (1), p. 6, figs. 1, 2 and 3, P1. i, fig. 1 (1907) ; Ulmer, Cen. Insect., P1. XXIX, fig. 3 (1907).

This magnificent species, which is common in China, as well as in India, is not rare in Japan.

The manner of flight of this species rosembles that of a certain moth. Occasionally they are found on the bark of trees closely resembling the colour of the forowings, which always cover the abdomen and beautiful hind wings, when they are at rest.

Already reported from Hokkaido and Honto.

2. Neuronia reginella sp. nov.

Head blackish, clothed with brownish hairs, cspecially on the face; vertex wholly fuscous; ocelli brown; labial palpus consisting of four joints, brown; maxillar palpus four-jointed, the last joint more slender than others and fuscous; all the others mostly brown and each thickened at extremity. Antennæ lost, except two basal joints. Prothorax light brown with a median longitudinal impression, clothed with long, fuscous hairs. Meso-and metathorax 
fuscous, the former with stout fuscous hairs, the latter with long and weak gray hairs. Underside of thorax mostly brownish. Legs brownish, tibiæ and all the tarsal joints fuscous; spurs on tibiæ 2, 4, 4 ; hind femora somewhat dark, with a brown ring near the extremity. Fore wing light fuscous yellow, with fuscous markings, as shown in figure, with some stout blackish hairs at the base;

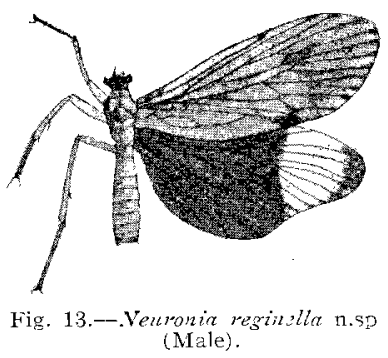

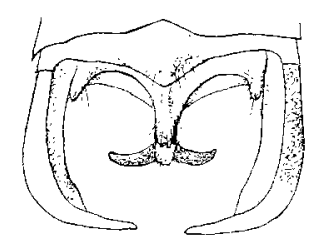

Fig. 14.--Nenronia rexinella (Male),

veins yollowish. Inner half of hind wing violet black, forming a broad, beautiful orange band betwcen this and the fuscous black apical spot. Abdominal segments blackish, fuscous on both dorsal and ventral sides, each segment with hind margin narrowly brown. Suranal plate in the genitalia of male individuals rather broad and little produced in its hind margin; superior appendage, with two small projections and many hairs on the cind; intormediate one separatod at the cnd of a small lobe curving little upward; inferior claspors stout and long, suddenly becoming much more slonder near its cnd.

Length of body $20 \mathrm{~mm}$; length of fore wing $33 \mathrm{~mm}$.; length of hind wing $28 \mathrm{~mm}$.

The type is a single male specimen in the collection of the Imperial Agricultural Experiment Station at Nishigahara. The specimen was captured by Mr. Murata at Nikko, on July 28 th.

This species is closely allied to Neuronia regina, which is a little larger, but the differences in the genitalia, mouth parts and wing markings scem to me to warrant the specific separation of the two forms.

3. Neuronia clathrata Kolenati.

Anobolia (Oligostomis) clathrata Kolenati, Gen. ct spec. Trichoptera, i. p. 82 (1848). 
Neuronia clathrata Walker-Cat. Neuropt, Brit. Mus., Pt. I, p. 7 (1852); Matsumura, Journ. Coll. Agr. Tohoku Imp. Univ., IV, p. 16 (1911).

4. Neuronia phalanoides Linné.

Phryganea phalcenoides Linné-Faun. Succ, p. 378 (1761).

Holostomis phalcenoides Walker-Cat. Neuropt. Brit. Mus., Pt. I, p. 6 (1852).

Neuronia phalcenoides Matsumura-Journ. Coll. Agr. Tohoku Imp. Univ., IV, p. 15 (1911).

The above two specics occur in Europe and Siberia, and have becn described by Matsumura, (1. c.) from Saghalien. It is said that a few spccimens have been obtained at Solowiyofka, Chipsani and Galkinowraskee, on that island. No specimen before me.

5. Neuronia apicalis Matsumura.

Neuronia apicalis Matsumura-Thous. Ins. Jap., I, p. 172, P1. XII, fig. 11 (1904); Matsumura-Journ. Coll. Agr. Tohoku, Imp. Univ., IV, p. 15-16 (1911).

6. Neuronia fuvipes Matsumura.

Neuronia fluvipes Matsumura-Thous. Ins. Jap., I, p. 172, Pl. XII, fig. 12 (1904).

Unfortunately, neither $N$. apicalis nor $N$. Amvipes, both of which were described by Matsumura about ten years ago from Hokkaido and Honto, are represented in the material before me. The same professor recorded the former from Saghalien, also.

7. Neuronia melaleuca MacLachlan.

Phryganea melaleuca MacLachlan-Journ. Linn. Soc. Lond., Zool., XI, p. 106 (1871).

Holostomis melaleuca Matsumura-Thous. Ins. Jap., I, p. 166, PI. XII, fig. 2, \& (1904).

Neuronia melaleuca Ulmer-Doutch. Ent. Zcit., p. 339 (1908).

The spccimens in hand, which I believe to be true $N$. melaleuca, differ to a certain extent from that species as described and figured by Matsumura in his "Nippon-Senchu-Zukai" (Thousand Insects of Japan), though the too meagre description does not enable me to satisfactorily determine it. It may be doubted whether Matsumura's identification of his specimen with $N$. melaleuca be justified. 
In any case it may safely be said that there is another form in Japan besides $N$. melaleuca, closely allicd to this sfecies. It is said that the habits of this species rescmble those of $N$. regina.

Habitat-Hokkaido, Honto.

Genus Phryganea Linne.

8. Phryganea japonica MacLachlan.

Phryganea japonica MacLachlan-Trans. Ent. Soc. Lond., (3) V, p. 248 (1866); Matsumura-Thous. Ins. Jap., I, p. 167, Pl. XII, fig. 3, ơ (1904); Ulmer-Cat. Coll. Selys, Fasc. VI (1), p. 10, figs. 11, 12 and 13, Pl. I, fig. 2 (1907); Ulmer-Gen. Insect., PI. XXX, fig. 1 (1907).

The markings of the fore wing of this species are subject to variation, and the material before me can be separatcd into two types:

(i) Those that have conspicuous fuscous lines along the cubital and the fourth apical veins.

(ii) Those that have faint and obscure fuscous lines along the cubital and the fourth apical veins.

Though there are some other minute differences in the markings of the fore wing ketwecn types $\mathrm{i}$ and ii, I think they are not worthy of specific rank, since I could not recognize any difference in the genitalia, nor in any other respects, that appear to be specific. Until a more comprekensive study of thcse two forms is publisked I shall have to includo thom in ore spocies, Phryganea japonica. It would le very interesting if their life-histories were known.

It secms to me that Ulmer's figure in the Selys Catalogue reprocents type $\mathrm{i}$ and his figure in Gerera Insectorum type ii Matsumura's figure scems to ropresent type i.

This is one of the most common caddisflies of the family in the Main Island of Japan, occurring also in Hokkaido.

9. Phryganea sordida MacLachlan.

Phryganea sordida MacLachlan-Journ. Linn. Soc. Lond., Zool., XI, p. 106 (1871); Ulmer-Cat. Coll. Selys, Fasc.VI (1), p. 8, figs. 6-10 (1907).

A single female specimen in the collection of the Imperial Agricultural Experiments Station, from Gifu, labeled "Hayafumiyama." 
10. Phryganea latipennis Banks.

Phryganea latipennis Banks-Proc. Ent. Soc., Wash., VII, p. 107 (1906); Ulmer - Cat. Coll. Selys, Fasc. VI (1), p. 10, figs. 14-20, Pl. I, fig.3 (1907).

A single male specimen in the collection of the Agricultural Experiments Station, from Gifu, where the type specimen of this species was obtained.

The above two species secm to be uncommon.

Genus Limnoceutropus Ulmer.

11. Limnoceutropus insolitus U1mer.

Limnoceutropus insolitus Ulmer-Cat. Coll. Selys, Fasc. VI (1), p. 14, figs. 21-23 (1907).

This is the single species of the genus Limnoceutropus, and is knowin only from the female. I have not seen specimens of it.

Taken at "Nikko, 600-2000 m."

Komagomo-Higashikatamachi, Tokyo, Japan.

\section{THE OCCURRENCE OF THE MYMARID GENUS COSMOCOMOIDEA HOWARD IN AUSTRALIA (HYMENOPTERA).}

By A. A. Girault, Nelson, N. Q., AUstralia.

The following remarkable mymarid represents the fifteenth genus of the group known to occur in Australia. The original description of the genus is not accessible to me just at present, but I should call attention to the fact that the tarsi are five-jointed, not as in Polynema, as the name would lead one to infer. I have a specimen of the type of the genus, one of the series on which the species was founded, but not a type.

Genus Cosmocomoidea Howard.

1. Cosmocomoidea renani new specics.

Normal position.

Female.-Length $2.00 \mathrm{~mm}$. Large for the family. Shining black, the bulla of the scape, cephalic legs, trochanters, knees, proximal four tarsal joints and tips of tibia, rich brown. Wings conspicuously infuscated at tip (about distal fourth), the proximal

Cutcber. 1913 